\title{
Mediating mediations of the past: Monu- ments on photographs, postcards and social media
}

\section{Eirini Papadaki}

Classical and contemporary monuments are widely depicted on images produced and circulated by the tourist industry. They appear on personal photographs of visited places, functioning as souvenirs on notice boards or social media profiles. This paper examines the transformations of three-dimensional monuments in two-dimensional mediating practices and their socio-cultural and media settings. Moreover, it looks at the role of such visual resources in the overall signification process of specific sites and places. This examination will consider the practices of three visual mechanisms: postcards, tourist snapshots and images circulated via the Internet and specifically through social media. The paper proposes a similar ontological characteristic between monuments and photographs: their ability to capture selected instances of time and feed or shape memory.

\section{Keywords}

monuments, photographs, postcards, social media, semiotics.

\section{Introduction}

The reasons for the wide circulation of monument images in modern societies are their public character, aesthetic value, character as history narration devices, strong connection with places and signifying practices, used to make identifications, stress localities and shape identities. Monument images are seen in films, various television narrations - such as TV series, advertisements and documentaries - tourist guides, brochures, leaflets, airline magazines, music videos, video games, flooding our imagescape with their structures. Almost all the culture industries recycle such images, in an eternal recasting of the world's cultural capital. These repeated reproductions can be compared to Baudrillard's simulacra (Baudrillard 1994), mean- 
ingless bodies of visual stimuli with no real referent, shaping preformed tourist gazes (Urry 1990) and offering ready-made perceptions to potential audiences. From another, more optimistic perspective, they can be praised as a democratization of cultural resources, invitations to experiences (Papadaki 2006b), guides to the perceivers' gazes and therefore indirect knowledge acquisition strategies. There are many gazers, of course, that deny instructions, following Hans Keller's (1987) beliefs that it is better to travel without a guide, exploring and discovering the newly visited place/cultural sign by oneself, following one's own aspirations, expectations and desires. Tourist photography can be seen as a way for a gazer to autonomously find the sites that he/she considers valuable of the photographic shot and the simultaneous entrenchment to acquisition, recollection and memory. Unquestionably, the tourist's familiarity with the mediated images of monuments or tourist sites, coded as identifying or topos-authentical mechanisms, forms predetermined guided gazes that work as a "treasure hunt" for every destination newcomer: every tourist holding a camera try to find the must-see sites of the visited land, photograph them and post the results on his/her social media profile - as acquired "trophies" from the invaded, exotic other (Papadaki 2004). As the Grand Tourist before him, the modern tourist follows a specific ritual: been there, done that, got the certificate (be it the souvenir, the postcard and more recently the snapshot or the selfie) and then put it on display (in one's living-room, on notice-boards, or more recently on social media posts). Even so, as every game, so the tourist 'treasure-hunt' of the pre-seen images, played when transcending 'imaginative geographies of places' (Larsen 2004: 242), entails improvisation and playfulness, genuine production, instead of sheer reproduction practices. The tourist as cultural producer is highly referenced in the bibliography of tourist studies (Edensor 2000; Larsen 2005; Scarles 2009; Haldrup and Larsen 2010).

Images on tourist brochures and other tourist agents, as well as the images mediated through such cultural industries as film, music or the media generate predetermined gazes at places, but also foster anticipation to visit the foreign lands and the objects depicted. Postcards invite tourists to explore beyond such images as they carry pictures of food, traditional musical instruments, or scenes from everyday lives of the place's inhabitants, signifying sentiments such as smell and sound and/or stressing otherness.

This paper examines the mediations of monuments as artworks and historic narrations, focusing on their signifying roles, through the analysis of three visual devices: postcards, tourist photography and relevant image posts on blogs and social media. The selection of the three modes of image discourse aims to follow what Robinson and Picard (2009) see as parallel, yet joined systems of representations: professional versus amateur images, widely communicated and alluring images versus personal mnemonic photographs of one's past holiday instances whether shared on noticeboards, in friends' gatherings or via the social media. Therefore, the specific devices were chosen as representative examples of the collective gaze, the personal gaze and the digital gaze respectively. They all focus on image discourse, leaving side for the 
linguistic only as a small commentary on or in the back of the image (postcard), during the discussion between friends/family (tourist photography) or as captions/hashtags/comments under the image in the digital environment (social media posts).

To study the influences of mediation in the shaping of monuments' stories, it is first necessary to examine the nature of monuments as public art, as mediators themselves, as narrators of social pasts, and - most importantly for our research - as signs.

\section{Monuments as public art}

By the 1960s, monuments started to be considered as public art, as 'artistic production with memorial claims' (Salvatori 2015: 931), architectural objects or practices regarding the occupation of public space, sketching a distinctive image of the city. The experience of architectural objects is an engendered pleasure whether we agree with functionalism - seeing form as inseparable from function - with the theory of space - experiencing architectural objects as experiences of space; whether we see them through Hegelian eyes - as expressions of their time - or through the theory of proportion - as harmonious order, giving specific rules and principles for the combination of their parts. Agreeing with Scruton (1979), architecture can be perceived imaginatively, depending on the viewer's conception of the architectural object.

Monuments are chosen to be erected in central points within villages, cities, communities. They transform the image of the specific surroundings and the everyday image of the place's inhabitants, first aesthetically and in a second extent symbolically. Monuments are first and foremost public artworks. Their aesthetic value is as important as their historic narration.

\section{Monuments as mediators of social pasts}

Monuments are made to last and remind their viewers of the times they were built. The word's root is the Latin monere, which means to remind. Monuments are therefore, apart from aesthetic architectural items, maintainers of memory and reconstructions of hegemony (Miles 1997: 74). If Connerton is right in saying that 'our experiences of the present largely depend upon our knowledge of the past and our images of the past commonly serve to legitimize a present social order' (Connerton 1989: 3) then the importance of monuments for shaping and maintaining social memory is quite straightforward. They function as traces or marks, something that our predecessors left behind and helps us appreciate and maintain social memory. Monuments enhance the significance of particular locations and enter the consciousness of the people who live around them. They represent a highly visible past and were created to make that past broadly known (Papadaki 2006: 60). 
As every part of history cannot be shaped in the form of a public monument, it is only evident that there are certain aspects of past events or specific heroic people that are chosen to inspire a monument's theme. Monuments have been criticized as only partly representing history, deliberately hiding uncomfortable aspects of it, even intentionally falsifying it. Political wills and image making play an important factor in the decisive process regarding the represented subject, the kind of monument, the specific form, the artist and the place that will host the final creation. It is exactly this manipulation of history by political authorities that explains the various protests and demonstrations expressed for and on the site of certain controversial monuments by the inhabitants of the place, reaching to the extent of damaging, altering or even demolishing the specific monuments.

The study of the relationship between monument and document has been extensive in the writings of Foucault and Le Goff during the 1960s and 1970s. There is also much scientific discussion on the gradual distancing from the traditional notion of the big, stable, representational monument-statue to more abstract, contemporary art installations, where 'collective and individual experiences basically intersect' (Salvatori 2015: 932), aiming at the production of 'plausible supports for memory, even when they undermine the traditional forms of commemoration' (Salvatori 2015: 934). New terms such as anti-monuments, counter-monuments (Young 1990), immaterial or invisible monuments (Wajcman 2010) describe places that 'provide time for memorial reflection' (Young 1999: 9), offering a process, not a definite and unquestionable answer to the acquaintance with or the perception of historic narratives.

\section{Monuments as signs}

The most important attributes of monuments, however, is their signification practices (Bellentani and Panico 2016) or the symbolic metaphor they are shaped to express. Monuments are shown and seen as major signs of people and places: they "belong to the universal language of travel' (Barthes 1979: 4). Symbols from the ancient world, such as columns, obelisks or wreaths, arches or creatures with wings are commonly used on monuments' bodies to signify loss or death and victory or hope respectfully. In addition,

[...] materials and forms are often endowed with a visual appearance that "translates" their functional and tactile qualities [...]. I may see a shape as "hard" or "soft", as "welcoming", or "hostile" [...] it must be possible to see not only colours and shapes, but also such properties as warmth, mass, solidity and distance. (Scruton 1979: 96)

Economic constraints of monuments' construction, visible in the selection of the materials 
used, can also promote specific messages to their viewers. The symbolic language of monuments, the codified purposes of the marble/bronze/stone bodies of statues/columns or other structural forms made for commemoration, are carefully studied before the formation of the final monument, during its interaction with the public (both inhabitants and tourists) and sometimes after its de-construction, in order to be transferred to another place, to be hidden in a state building or even destroyed. The historic event chosen to be represented, the point in the city selected to host the specific representation, the material, size, aesthetic choices of the creator, all add to monuments' signification process. It is broadly believed that the commissioning of statues and memorials proclaims the manufacture of a national cultural identity. It is that symbolic identity, that otherness, that will in later stages attract the gazes and the photographic shots of the tourists visiting a place.

To name just one example of a well-known sign-monument, I will refer to the Statue of Liberty which, according to Warner (1987) is identified with an American ideal of democracy. 'The sensual pleasure of the eye, when looking at the specific statue, is therefore, dependent not upon aesthetic delight but upon the psychology of vision' (Warner 1987: 13). We are looking at Democracy itself. Even so, Warner emphasizes the argument that the interpretation of each monument depends on the viewer. Monuments are encouraging us to find our own meanings through their marble bodies. Photographs and postcards can help make that interpretation personal, turning the social image into a personal souvenir (Papadaki 2006). A monument snapshot or a postcard can be seen as a captured personal memory fragment mixed with collective images (Lofgren 1999: 2; Papadaki 2006).

\section{Monument mediations}

Classical and even some contemporary monuments are widely mediated through tourist agents such as brochures, postcards, posters and digital narratives like tourist sites, blogs and social media. Some monument mediations transcend the sphere of the tourist industry, intermingling with symbolic content from other cultural industries, such as the movie industry, the music industry, video games and of course the media. The visit to the actual place is then translated as an attempt to see and admire the original referent of a familiar image - the true monument seen already on paper or screen - bringing forth the Benjamian thoughts on aura, ritualistic value and politicization of aesthetic objects. The Eiffel Tower, the Acropolis, the Pyramids are monuments everyone has heard or seen something about. Hardly any schoolbook, poster, postcard or film does not hold one of their images. To enter into one of those monuments is thought of as to enter into a historical or aesthetic sacred. This idea gives travelers the sensation of a power of intellection, as in front of the monument they try to remember and combine all the things they have heard and seen about the particular monument and then decode and understand it, solve its "puzzle" (Papadaki 2004). As Barthes explained (1979: 14) 'to enter a monument is to solve, to possess it'. 
This procedure of decoding is highly influenced by the images and the narratives circulated through the cultural industries' repertoire. The visitors/tourists of a specific monument carry with them all the previous encounters they might have had with the object, direct or mediated, having already shaped a particular interpretation of its signifying practices.

Research shows (Robinson \& Picard 2006; Ek et al. 2008; Sun et al 2014; Santos 2016 among others) that official mediations of monuments that appear in brochures or guidebooks usually offer overall views of the selected monument, focusing on its size, material and/or signifying practices. The photographs chosen to be included in such media are taken by professional photographers and follow specific photographic practices: distant view for the whole construction to appear in the image, powerful light offered through clear blue skies and general beautification techniques so that the monument to appear spotless and inviting. The text embraces the images, giving information on the object appearing in the photograph, its history, its relation to the place hosting it. These kind of tourist agents - the media that are meant to offer helpful instructions for the travellers and are therefore bought by the latter before their travel to a specific destination or before their get to a specific site, as the guide books and brochures mentioned above - are believed to hold the representative images of the place, the ones that will offer the first clues for the tourists' 'treasure-hunt' game when in the visited site. The mere appearance of a specific monument on the pages of such a medium simultaneously applies to the monument the label of a place's, a society's or a nation's sign.

Among the tourist agents wishing to attract the collective gaze, I will examine the postcard. The specific choice was made for many reasons. Firstly, because of the postcard's long-lasting appearance in our houses. The postcard is cherished, valued, stored. Either as a souvenir of one's travels or sent to us as a message from a friend or family member, the postcard is kept and looked for, unlike tourist guides or brochures which are dismissed the very moment they fulfil their role. In addition, as the focus of this paper is the pictorial mediation of monuments, the postcard is selected as a cultural resource that prioritizes image over text, despite the fact that it can, of course, be seen as a multi-modal representation mechanism, according to Kress and Van Leeuwen's (2006) discourse. Furthermore, the postcard is addressed to a bigger audience as its messages' recipients include travellers, collectors and the receivers. As such, it cannot be considered as an 'official gaze', as it is not produced by national or local authorities, like official tourist guides and leaflets and because it has unquestionably formed new grounds for both tourist photographic practices and tourist communication. Lastly, the postcard's signification strategies are rather powerful and relatively understudied. 


\section{Monuments on postcards}

As Jaworski (2012: 570) explains, 'despite its relatively humble status as a mass-produced, cheap and disposable artefact, the postcard has been an important and influential genre shaping the collective social and cultural imagery of the world since the beginning of the twentieth century'. Either as Lury's 'tripper-objects' (Lury 1997: 79), i.e. things that are meant to be brought home as souvenirs or as collection items, as quasi-mass media in corner shops ( $\mathrm{Pa}$ padaki 2001) or as sent to friends, postcards transfer messages and stories to distant places. Postcards 'shape collective ways of imagining people and places' (Jaworski 2012: 571) and are therefore believed to aim at the collective gaze.

Monuments, both classical and more contemporary, are one among the favourite themes depicted on postcards. The highly localized quality of monuments, their character as public objects, being works commissioned for a site of open public access, make them classic postcard images addressed to tourist gazes (Papadaki 2004). The postcard of a monument in a central square, for example, characteristically proves the function of a postcard as a souvenir. The monument is framed by its location in the particular social setting and this setting is what provides it with meaning and cultural value. Its highly localized quality is straightforward: there is no second copy of the monument anywhere in the world. Its authenticity makes it a classic city view site. Its existence at the particular spot - the spot being strictly related to the monument and vice versa - lends some authenticity to the place, making it classic as well. The spot then characterizes the whole city, becoming one of its main collectors of tourist gazes (Papadaki 2001). Through the postcard's 'staged authenticity' (McCrone et al 1995:46), the monument becomes the city's symbol. The name of the place printed on the monument's photograph, text and image intermingled, makes their separation impossible: the monument characterizes the place; the place's name should instantly bring in mind the place's monuments as its signs.

The tourist industry uses photographs and postcards of monuments as destination branding mechanisms (Papadaki 2017).

Perhaps what is appropriate of a monument on a postcard is its value as a public representation of human life: appropriate for the tourist, that is, in that it is seen as a trophy from the visited country. He managed to acquire something sacred and authentic, because it is part of the difference and therefore uniqueness of the visited place, and that is why he sees it as a trophy. (Papadaki 2004: 367)

Postcards show whatever their producers think would give prestige to their countries whatever they think would make them look both aesthetically attractive and culturally significant. Monuments are one of the best cases that could make this aim easily and directly met, 
as they are seen as high-status sites. The monuments that appear on postcards are the ones that look good in photographic reproduction. ${ }^{1}$ The Eiffel Tower is for Barthes (1997) a universal symbol of Paris and therefore it is everywhere on the globe where Paris is to be stated as an image.

There is extensive scientific research on the relation between the architectural and the archaeological with photographic practices (e.g. Shanks 1997; Hamilakis 2001, 2008; Papadaki 2001, 2004; Bateman 2005; Downing 2006; Smiles and Moser 2005; Cochrane 2007), but very few papers appear in the scientific community on the procedures at work when a monument is captured by the photographic lens. Photography was from its first steps associated with archaeology and antiquities, as the world's classical monuments were one of the first favourable photographic subjects. 'The first daguerreotypes of the Athenian Acropolis were produced in 1839, the same year that the process had become officially known' (Hamilakis et al. 2009: 286). Archaeological sites, as well as classical monuments and antiquities were photographed as autonomous structures, isolated from the nearby buildings, traffic and citizens walking by. A photograph is able to isolate, but also 'to define, interpret, exaggerate or even invent a cultural value' for the photographed object (Campany 2014: 15).

As Hamilakis et al point out (Hamilakis et al 2009), both domains acquired clearing and exhibition strategies in order to attract tourist gazes: archaeology cleared and reconstructed sites and classical monuments, while professional photographers framed out of their optical angle traces of contemporary life and preferred images of isolated classical or more recent monuments, offering objectified gazes for tourist consumption. Notions of attention management (Crary 1992) or autonomous vision, a new visual economy (Sekula 1981), disembodied vision, spectacle and surveillance were examined in the new framework.

Details, close-ups, distances and various view-angles, whatever the eye misses could nowadays appear on a postcard, trying to attract both the romantic gaze and the cultural tourists' interest. Among the picturesque landscapes and the traditional settings, a postcard may carry images of a monument's detail, adding to its signifying power. An image of timeless stillness, a frozen moment, with no people involved, is offered to the viewer as a gift-image. The illusion that the person holding the postcard is the only viewer is enhanced by the absence of other people, the disassociation from the rest of the cityscape and the way the monument is captured, lightened, brought to the foreground. Unspoilability and remoteness are desirable tourist markers, as Cohen (1989) explains. The caption on the image or behind it can identify, explain or give information about the picture or combination of pictures shown.

Of course, a postcard view of a monument or public statue embodies a relation to the city these architectural objects are taken from. The monument is photographed against a background, which is usually formed by the nearby buildings and general surroundings. 'The specific surroundings of a square, park or street contain many extra signifiers that guide our reading of the images in question' (Sterkx and Engelen 2013: 446). In postcard photographs of more 
contemporary monuments aimed at the romantic gaze, passers-by walking nearby or kids playing often enrich the photographic scene, signifying the interplay between the monument depicted and the everyday practice of the inhabitants of the place where it stands. In antithesis with the isolated monument-sign on a postcard, these kinds of images suggest that the background of the monument offers necessary information without which any interpretation is not possible. In this context, the monument is seen as part of the city, in a constant dialogue with the physical and technical surroundings, in an eternal interaction with local people.

The landscape orientation is chosen when these surroundings are meant to be visible and meaningful to the gazer of the postcard. Portrait orientation is preferred when the monument is photographed against the blue sky, from a low angle, stressing the monument's size and its imposing character. Sterkx and Engelen (2013) believe that picture postcard is a photographic genre in its own right, an interaction between art studio photography and snapshot photography.

In a complete analogy, similar to the monuments' role as devices of social control, a way to make people forget some aspects of their history and remember others (Papadaki 2006), postcards can be seen as visuals for tourist consumption, stating a place's narrative that is far from being neutral. Both standing in a complex relation to time, the monument and its mediation, namely the photograph on the postcard, make choices, produce meaning and form social and cultural value. The capacity of monuments to signify the social past is already evident in the present text. The capacity of photographs to create symbolic capital has also been proven (Tagg 1993; Edwards 1996).

Postcards can be seen as carriers of the monument's cultural charisma and transmit it to the gazer (Papadaki 2004). Through photography, the 'taste of the personality of a society' becomes visible to people outside the specific society (Shore 2008).

One cannot visit one of the world tourist destinations without visiting the corresponding monument and usually the visit ends by a look at the little shop situated near the exit. It is, as I have already pointed out, the tourist's little ritual: to travel somewhere, visit the well-known sites and the famous monuments and buy himself/herself a souvenir to remind oneself of a past experience and show to the friends and family. (Papadaki 2004: 365)

The more familiar the image on the postcard, the more proof that one has visited the place. The famous monument on the postcard also lends some of its pride and cultural status to the visitor - only cultural people visit cultural sites - and consequently to the receiver of the postcard. According to Kürti (2004: 47) 'postcards certainly have assisted in the popular mediatisation of our lives with the use of (Foucault's) heterotropias'.

In an attempt to examine the nature of the mediation practices used when transferring the image of a monument, I will recast the character of the photograph as a mechanism capturing 
not only the image, but also the essence of the featured monument, as well as the memories of the photographer.

\section{Photographs as monuments: Mediators of personal pasts}

As Buck-Morss' (1992) prosthetic sensory device, Freud's 'artificial memory' (1984: 430) or Benjamin's (1969) technological enrichment of human sensory perception, the camera captures specific moments that the hand holding it finds worth keeping. Most of the people living in developed countries own a camera. A plastic eye that accompanies the visitor in his trips, a device to experience the world through lenses. The photograph arrests reality, but the individual is involved in the deliberate cropping of reality through the lens. A photograph is reality seen through the photographer's eyes.

What is photographed seems to be acquired by the owner of the camera. Through photographs, one sees reality having the chance to hold in his hands and ponder on people, experience and information (Papadaki 2006: 55). Most people own photographic dossiers - albums - and try to collect as many photographs as they can, to classify their experience through its existing pictures, to create a chronological file of events, beloved people and memories. Time passes and the only thing one can be positive of concerning his past experiences is the moment those photographs were taken or given to him. Photographs cease to be an instrument of memory, helping to reinforce it. They are starting to function as an invention of it or its replacement (Sontag 1977).

In a sense, a photograph can be seen as a monument of one's personal history (Cavallucci 2010), as it choses specific viewpoints to record past moments. A photograph entails personal choices, individual aesthetics and framings based on the photographer's aspirations, cultural background and previous knowledge.

Photographic practice, however, can also be influenced by social factors, as well as the unconscious adopting of an imagescape shaped by the media and specific tourist agents. As Bourdieu (1990) suggests, agreeing with Berger (1972), photographic practice is socially patterned and learned, determined by family function and ordinarily associated with the high points of family life. It cannot free itself from the occasions that determine it and turn into an autonomous practice. Everyone takes pictures of and within the contexts of their family. 'It is via the family group that the primary function of photography becomes the responsibility of the photographer, who is asked to solemnize important events and to record the family chronicle in pictures' (Bourdieu 1990). The family album expresses for Bourdieu the essence of social memory (Papadaki 2006: 56). Fish's 'interpretive communities' (1980: 150) come to underline the similarities of encoding and decoding practices between members of the same group of people, be it family, co-students, colleagues, inhabitants of a place or tourists. 
Many researchers focus on the strong bond between travel and photography (Sontag 1979; Larsen 2004; Robinson \& Picard; Scarles 2009; Santos 2016). Photographic practice is paralleled with tourist practice and in many cases the two are seen as inseparable. Scarles (2009) sketches photographs' characteristics as political artefacts, reflexive performances, the imagination of space, embodied visualities and ethical prompts. The politicization of photography lies on the pre-existence of certain gazes (Urry 1990), offered by tourist actors and media, predetermined staging (Edensor 1998) or cultural scripts (Baerenholdt 2007). All these pre-seen, framed gazes are seen by Scarles as 'signs that guide tourists' interpretations' (Scarles 2009: 474), as tourists tend to capture with their cameras what is already captured by professional photographers or circulated through the tourist industry's agents and the media. Photographs, however, have a strong connection with memory, remembrance and rethinking on past moments and previous gazes. As reflexive performances (Crang and Travlou 2001) or windows to one's past instances, photographs are re-examined, talked about, shared and commented. Photography is not exhausted in the capturing instance of the heard shot. It is on a later stage selected, printed, displayed in frames or shared via the social media. In its second living instance, photography helps tourists re-live experiences through reflexive intimacy (Haldrup \& Larsen 2003). The photograph, especially when printed, is tangible and present whenever searched for, available for re-casting one's gaze upon, able to offer to its holder glimpses to past experiences.

The imagined is interwoven with the real in a tourist's photograph while implying active, embodied engagement and actual action (Crang 1997). It is self-evident that ethical issues may arise regarding the power of the photographer over the photographed other.

Returning home, the tourists carry cameras - or other photographic devices, such as mobile phones or tablets - with a large number of photographed materials, among which many pictures of monuments, both classical and more contemporary. These were the images they were meant to find in the foreign land, were they follow the instructional gaze encountered through their media wanderings.

\section{Monuments on photographs}

One must take 'endless precautions in Paris not to see the Eiffel Tower' (Barthes 1979: 3). Monuments' role as landmarks of particular locations is non-negotiable. In front of a most celebrated monument the tourist poses placing him/herself near the charismatic signs of difference and otherness. One can see the queue of people who want to be photographed in the same scene, taking an identical posture with the one photographed before them (Papadaki 2006: 56), controlling 'the objectification of one's own image' (Bourdieu 1990: 83). The photograph of a traveller in front of a monument can provide aesthetic experience as well as 
memories of personal thoughts and feelings felt while being at the site. The photograph does not function only as a souvenir of the buildings and statues seen there, but also as a souvenir of my being there, as a souvenir of my past experience.

With the monument as background, the tourist poses in front of the photographic lens. Certain site symbolisms inspire various types of performances, as Stylianou-Lambert (2002) shows in her research on tourist photographic practices in front of Aphrodite's rock in Cyprus. 'Different roles, scripts, choreographies, group formations, instructions and cues are followed' (Edensor 2000: 326). Robinson and Picard focus on the evocation of play in the tourists' photographic narratives. Hom-Cary (2004) talks about 'tourist moments', the connection with the other, the temporal intimacy of the tourist with the visited place.

A photograph of a monument makes the moment objective, as Terdiman (1993) would say. If no other person is nearby, the photographer captures the site with his/her camera. He/ she has the impression of owning it, when holding the print paper on hand or when looking the site's digital analogon in the camera. This is the reason for the long queues of tourists standing patiently to be photographed in front of a well-known site: they prefer waiting for hours for the spot to be clear of other people, then to photograph themselves besides other tourists. They are willing, of course, to be photographed along family and friends adding more images to the snapshot versions of life (Chalfen 1987).

Social media offer to the photographer the opportunity to write a small text, a caption or a comment underneath each photograph, including hashtags, as an interpretation of the photographed entity that helps towards the decoding of the formed message.

\section{Monuments on social media}

Social media are important channels distributing information on cultural resources nowadays, whether as an outcome of a formal organization's or a professional's effort to communicate with a targeted audience or an individual's personal photo narrative. In recent times, such images are uploaded in social media profiles, underlying the status and cosmopolitanism of the photographed subject (Papadaki 2014) and/or shared between online communities. Social media can be seen as a vast archive of photographic representations of monuments. The levels of engagement, interactivity and participatory experiences that can be offered through social media are the focus of many recent research articles and it is widely accepted that 'the ease of translation from one type of engagement to another' (Shanks \& Svabo 2013) is bigger than ever before. Technoculture tells the tale. Moser (2009) underlines the way people participate in a more collaborative, co-creative way when playing computer games. Monuments have appeared on video games and even named some, like the 2014 Monument Valley.

Urry's 'imaginative mobility' (2011: 155) and bodiless travel through books, film and tele- 
vision has been extended to include digital travelling, including browsing through official sites of world destinations or gazing the posted snapshots of friends when abroad. The eWoM ${ }^{2}$ mechanism works parallel to the circulation of status-enriched portraits or selfies of travellers in front of the most celebrated world monuments.

The difference of the digital photography lies on the element of time: the selfie is taken and uploaded in a few second on social media profile, in antithesis to the classic tourist snapshot that was printed, framed and displayed in one's living-room, stored in a photo album or shown to friends and family on an occasion. The digital photograph can therefore be seen as being directed towards an immediate audience (Larsen 2008), forming the contemporary 'culture of instantaneity' (Tomlinson 2007:74).

In social media posts, monuments are added to personal narration, in a sort of diary or chronicle of life instances. They both transmit their charisma to the person photographed in front or besides monuments and help the digital gazers get to know or interpret them. In this sense, photographs of monuments in social media aim at targeted audiences, i.e. the photographer's or photographed friend network. The personality of the person that is photographed or commented on the photograph may influence the viewers' perception of the monument. A funny posture near the monument sketches the humorous potentials of the spot, a romantic hug of a couple makes the monument romantic and so on. The captions, hashtags or comments of the creator of the post also guide towards the creation of the monuments' meanings, just like the hand-written message on the back side of the postcard did.

The reactions to the posts could also shape the monument's popularity or fame. The photographs and selfies uploaded to social media ask for likes, shares, comments. The number and the kind of such reactions add to the monument's story, re-creating its meaning and visiting value.

\section{Conclusions}

Monuments carry important messages. They are meant to tell past tales to their visitors, both locals and tourists. Different interpretations can arise among these two interpretive communities. For locals, monuments will evoke memories from lived experiences or from known facts of their past: either way the sentimental bond is apparent. Having been placed in particular environments, monuments enrich the location's significance and are usually connected with commemoration ceremonies, adding more memories to local people. Tourists, on the contrary, see the monument in a simpler way, as a step in their search for the views already seen in various media before the trip. They pose in front of the monument with wide smile and carry the photographs back home as souvenirs, mementoes or trophies, or post them online, as their personal photo-narrative. 
According to Warner, monuments are given meaning by their viewers and it can change according to what they see or want.

The Statue of Liberty does not record the past, except for the allusion to the Declaration of Independence. It anticipates continuously a future that is always in the process of becoming: hence Liberty's determined step forward, her lamp held up to illuminate the space we cannot see, the time to come. She expresses intention, more emphatically than act; we are all subjects of incorporation in that regard. We all hope to be free, we could all be free. (Warner 1987: 14).

Freedom is different from the one person to the next. The idea of the anticipated future may be common to all those people standing in the crown of the Statue of Liberty, but exactly what each of them is determined to make out of that future is another matter. As we place our heads in the hole made as Liberty's head at a paper imitation of her we are the ones who step forward, waiting for the future. It takes a lot of imagination to take part in a process of recreating a past that is later recalled and of making it play an important role in the present.

Even if for Warner the statue of Nike represents a town's victory, its fortune or Tyche, its triumph, if the statues of angels are seen as success, glory, reputation or fame, she concludes that monuments are for rent. There is no set meaning. The interpretation depends on the viewer. Monuments are encouraging us to find our own meanings through their marble bodies. It is not that there is not a correct way of seeing them. Nike is a town's Tyche and a body with flying wings that will continue to symbolize triumph. But we can see it as our own personal triumph at our own personal achievement. Postcards can help make that personal interpretation ours.

Through mediation, the monument is equaled with the society's identity or differentiation, when the place's name is written on its paper surface or tagged online as its seal and undistinguishable attribute (Papadaki 2004). On photographs and postcards, monuments are practically without function: 'they are in the first place expressions of identity' (Warner 1987: 6). Despite the admirable aesthetics and form of the Parthenon, on a postcard it only is an Athenian symbol and a sign, trace or mark of human democracy. On posters, in films, on books and in newspapers the Statue of Liberty has been used for many different purposes. To provide a classic American image, to legitimize political campaigns, to seal a statement with moral dignity and so on. On a postcard, Liberty is seen as identification of the city and by extension the nation.

The three devices chosen for this study (postcards, photographs and social media) serve the commodity, the tourist and the digital gaze respectively. They all make an abstraction of the monument from three to two dimensions. They can work as mnemonic devices or traces to one's past and, at the same time, they can function as invitations to the visited site. They are all associated to - and for some are inseparable from - travelling and tourist practices. 
Spectatorship is nowadays constituted through mixed images: tour operators, postcards, the media, professional or personal photography circulated in the digital environment materialize or objectify the tourist gaze (Sontag 1979; Urry 1990). For Osborne the similarity between the postcard and the photograph lies in their role as 'quotations of mass-media views' (Osborne 2000:79). The dystopia of the passive viewer and photographer is common in the bibliography of tourist studies, cultural studies, media and communication studies. According to that point of view, personal photographs actually reproduce the themes of mass media discourses, feeding the 'vicious hermeneutic circle' (Albert and James 1988; Osborne 2000; Schroeder 2002; Urry 2002; Jenkinks 2003), or certain 'place myths' (Shields 1991), equating experiences with photographed moments (Sontag 1979) and reinforcing widely circulated media images (Boorstin 1961; Caton \& Santos 2008; Mellinger 1994; Urry 1990). On the other hand, more recent researches underline the energetic character of the site/monument gazer. In complete contrast with 'authorized heritage discourse' (Smith 2006: 5), photography is thought of as 'performed, rather than preformed' (Larsen 2004: 242). Tourists are seen as 'armies of semioticians [...] interested in everything as a sign of itself' (Culler 1981: 27). Gazing has been paralleled to a collection of signs or markers (MacCannell 1999: 41). The gazer (and photographer) is seen as highly interactive with the gazed environment, co-producing the interpretations and meanings of the newly discovered scenery. Finding the referent of the sign or capturing representative signs are, in themselves, creative processes.

Bourdieu (1990: 37) suggests that there are photographs which one must 'take' and sites and monuments that one must 'do'. Research has shown that tourists may be influenced by pre-established mediated gazes, but they actively re-construct and re-signify such images via creating their own (Garrod 2009; Scarles 2009; Stylianou-Lambert 2012). This practice is enriched and enhanced in the social media environment, where the receivers of the photo messages can actively interact with the monuments, commenting on it, uploading similar photos at the spot, as in a constant recreation of the monuments' meaning.

Both being mnemonic devices, photographs and monuments function in similar ways: photographs record personal memories, while monuments give shape to collective past instances. From the middle of the $19^{\text {th }}$ century, monuments play a significant role as commemoration vehicles (Le Goff 1992), creating a new notion of public sphere. At the same time, the historic events that are chosen to become visible public statements are carefully chosen and often refined as to be unobjectionable and rather likeable.

Photographs and monuments are similar sign systems. Photography cannot but be seen as an abstraction, a codification of the elements believed as necessary to represent a connoted past moment. A monument is a symbol of local and by extension national identity through the emphasis on specific historical narrations of a specific place. As Bate (2010) explains, one can find identity or identification within a specific common visualized memory. When appearing on a photograph, the three-dimensional monument is reduced to two-dimensions, a sign on a 
sign. 'The photograph has the capacity to incorporate and absorb many other already existing visual memory devices within photographic re-presentation' (Bate 2010: 248). Serving the modernist inquiry of producing images of 'the individual and national self as other' (Downing 2006; Hamilakis et al. 2009: 285), the camera captures people and national symbols on paper. The monument also freezes time, as it captures on its bronze/marble/stone body significant people or historical moments, functioning itself as a symbol of a particular place or an entire nation.

Both photographs and monuments create static, fixed positions that cannot be altered, capturing fragmented moments, past testimonies, connections to personal or social history, codes and narrations. Both photographs and monuments can serve as documentation, evidence of existence, mnemonic apparatuses and communicative media, transmitting to their gazers significant messages.

\section{NOTES}

1 Paraphrasing Benjamin, who wrote that the kind of art that will triumph will be the kind of art that looks good in photographic

$2 \mathrm{eWoM}$ is the acronym for electronic Word of Mouth. In this context it is used as a marketing strategy of inviting people to the monuments and destinations shown in a friend's post. The positive experience of a trusted friend works as a guarantee of one's own positive experience and a strong criterion for the decision to visit the specific place.

\section{REFERENCES}

Albers, C. Patricia., \& James, R. William 1983. Tourism and the changing photographic image of the great lakes Indians. Annals of Tourism Research 10 (1): 123-148.

Bærenholdt, Jorgen O. 2007. Coping with distances: Producing Nordic Atlantic societies. Oxford: Berghahn.

Barthes, Ronald 1997 [1979]. The Eiffel Towel and other mythologies. California: University of California Press.

Bate, David 2010. The memory of photography. Photographies 3(2): 243-257.

Bateman, Jonathan 2005. Wearing Juninho's shirt: record and negotiation in excavation photographs. In: Sam Smiles and Stephanie Moser (eds) Envisioning the past: archaeology and the image. Oxford: Blackwell, 192-203.

Baudrillard, Jean 1994. Simulacra and simulation. Trans. Sheila Faria Glaser, University of Michigan Press. 
Bellentani, Federico and Mario Panico 2016. The meanings of monuments and memorials: towards a semiotic approach. Punctum. International Journal of Semiotics 2 (1): 28-46.

Benjamin, Walter 1969. The work of art in the age of mechanical reproduction. In: Hannah Arendt (ed) Illuminations. New York: Schocken Books.

Berger, John 1972. Ways of seeing. London: Penguin Books Ltd.

Boorstin, Daniel 1961. The image-A guide to pseudo-events in America. New York: Harper Colophon Books.

Bourdieu, Pierre 1990. Photography: A middle-brow art, Trans. Shaun Whiteside, California: Stanford University Press.

Buck-Morse, Susan 1992. Aesthetics and anaesthetics: Walter Benjamin's artwork essay reconsidered. October 62: 3-41.

Campany, David 2014. Architecture as photography: document, publicity, commentary, art. In: Alona Pardo and Elias Redstone Constructing Worlds: Photography and Architecture in the Modern Age. London: Prestel

Cary H. Stephanie 2004. The tourist moment. Annals of Tourism Research 31(1): 61-77.

Caton, Kellee and Carla Almeida Santos 2008. Closing the hermeneutic circle? Photographic encounters with the other. Annals of Tourism Research 35 (1): 7-26.

Cavallucci, Fabio (ed.) 2010. Postmonument. Cinisello Balsamo: Silvana Editoriale.

Chalfen, Richard 1987. Snapshot versions of life. Bowling Green. OH: Bowling: Green State University Popular Press.

Cochrane, Andrew and lan Russell 2007. Visualising archaeologies: a manifesto. Cambridge Archaeological Journal 17 (1): 3-19.

Cohen, Erik 1989. Primitive and remote. Annals of Tourism Research 16 (1): 30-61.

Connerton, Paul 1989. How societies remember, Cambridge: Cambridge University Press.

Crang, Mike 1997. Picturing practices: Research through the tourist gaze. Progress in Human Geography 21(3): 359-373.

Crang, Mike and Penny Travlou 2001. The city and topologies of memory. Environment and planning D: Society and Space 19: 161-177.

Crary, Jonathan 1992. Techniques of the observer: vision and modernity in the nineteenth century. Cambridge, MA: MIT Press.

Culler, Jonathan 1981. The pursuit of signs: semiotics, literature, deconstruction. London: Routledge.

Downing, Eric 2006. After images: photography, archaeology and psychoanalysis and the tradition of Bildung. Detroit: Wayne State University Press.

Edensor, Tim 1998. Tourists at the Taj: Performance and meaning at a symbolic site. London: Routledge.

Edensor, Tim 2000. Staging tourist: Tourists as performers. Annals of Tourism Research 27(2): 322-344. 
Edwards, Elizabeth 1996, Postcards: Greetings from another world. In: Tom Selwyn (ed) The tourist image: Myth and myth-making in tourism. Chichester: John Wiley \& Sons, 197-221. Richard, Larsen, Jonas, Hornskov Søren, Buhl and Mansfeldt, Ole Kjær 2008. A dynamic framework of tourist experiences: Space冈time and performances in the experience economy, Scandinavian Journal of Hospitality and Tourism 8(2): 122-140.

Fish, Stanley 1980. Is there a text in this class, Harvard University Press, 147-174

Freud, Sigmund 1984 [1925]. The mystic writing-pad. In: On metapsychology: The theory of psychoanalysis. Pelican Freud, vol. 11. Harmondsworth: Penguin, 427-433.

Garrod, Brian 2009. Understanding the relationship between tourism destination imagery and tourist photography. Journal of Travel Research 47(3): 346-358.

Jaworski, Adam 2012. Linguistic landscapes on postcards: Tourist mediation and the sociolinguistic communities of contact. Sociolinguistic Studies Vol 4.3: 569-594.

Jenkins, Olivia 2003. Photography and travel brochures: The circle of representation. Tourism Geographies 5(3): 305-328.

Haldrup, Michael and Jonas Larsen 2010. Performing tourist, performing the orient. In: Michael Haldrup and Jonas Larsen (eds) Tourism. Performance and the everyday: Consuming the orient. London, New York: Routledge, 1-19

Hamilakis, Yannis 2001. Monumental visions: Bonfils, classical antiquity, and nineteenth-century Athenian society. History of photography 25 (1) 5-12, 23-43.

Hamilakis, Yannis 2008. Monumentalising place: archaeologists, photographers, and the Athenian Acropolis from the eighteenth century to the present. In: Paul Rainbird (ed) Monuments in the landscape: papers in honour of Andrew Fleming. Tempus, Stroud, 190-198.

Hamilakis, Yannis, Aris Anagnostopoulos and Fotis Yfantidis 2009. Postcards from the edge of time: Archaeology, photography, archaeological ethnography. Public archaeology: Archaeological ethnographies 8 (2-3): 283-309.

Keller, Hans 1987. Criticism. London: Faber \& Faber

Kress, Gunther and Theo Van Leeuwen 2006. Reading images. The grammar of visual design. London and New York: Routledge.

Kürti, Laszlo 2004. Picture perfect: Community and commemoration in postcards. In: Sarah Pink, Laszlo Kürti and Ana Afonso (ed) Working images. London: Routledge, 47-71.

Larsen, Jonas 2004. (Dis)connecting tourism and photography: Corporeal travel and imaginative Travel. Journeys: International Journal of Travel and Travel Writing 5 (2): 19-42.

Larsen, Jonas 2005. Families seen photographing: The performativity of tourist photography. Space and Culture 8(4): 416-434.

Larsen, Jonas 2008. Practices and flows of digital photography: an ethnographic framework, Mobilities 3(1): 141-160.

Le Goff, Jacques 1992. History and memory. Columbia University Press.

Löfgren, Orvar 1999. On holiday: A history of vacationing, Berkeley: University of California Press. 
Lury, Celia 1997. The objects of travel. In: Chris Rojek and John Urry (eds) Touring cultures: Transformations of travel and theory. London: Routledge, 75-95.

MacCannell, Dean 1999. The tourist: A new theory of the leisure class. Berkley, Los Angeles, London: University of California Press.

McCrone, David, Angela Morris and Richard Kiely 1995. Scotland - the brand. Edinburgh: Edinburgh University Press.

Mellinger, Wayne M. 1994. Towards a critical analysis of tourism representations. Annals of Tourism Research 21 (4): 756-779.

Miles, Malcolm 1997. Art, space and the city. London: Routledge.

Osborne, Peter 2000. Travelling light: Photography, travel and visual culture. Manchester: Manchester University Press.

Papadaki, Eirini 2001. The mediation of art through the mass media. Ph.D. thesis, School of Drama, Film and Visual Arts, University of Kent at Canterbury.

Papadaki, Eirini 2004. Mass-produced images of archaeological sites: The case study of Knossos on postcards. Visual Resources: An International Journal of Documentation XX (4): 365382.

Papadaki, Eirini 2006. Narrating personal moments through social images: Postcards as souvenirs of memorable instances and places. In: Kate Milnes, Christine Horrocks, Nancy Kelly, Brian Roberts and David Robinson (eds) Narrative, memory \& knowledge: Representations, aesthetics, contexts. Huddersfield: University of Huddersfield Press, 55-62.

Papadaki, Eirini 2006b. Indeed, audio-visual media could invite to aesthetic experience: three case studies. $3^{\text {rd }}$ International Conference of Museology. Mytilene. June 2006.

Papadaki, Eirini 2014. Portraying the self for the gaze of others: The case study of photographs in Facebook. In: Edie Lanphar and Phil Fitzsimmons (ed) Connectivity across borders, boundaries and bodies: International and interdisciplinary perspectives, Oxford: Inter-disciplinary Press.

Papadaki, Eirini 2017. Seducing the tourist gaze: Postcards as influential destination icons. In: Evripides Zantides (ed) Semiotics and visual communication II: Culture of seduction. Newcastle: Cambridge Scholars Publishing, 145-165.

Robinson, Mike and Picard, David 2006. Tourism, culture and sustainable development. Culture and development section, Paris: UNESCO

Salvatori, Gaia 2015. Stone or sound. Memory and monuments in contemporary public art. II capitale culturale: Studies on the value of vultural heritage. Vol. 12: 931-954. Available from: http://riviste.unimc.it/index.php/cap-cult. [accessed December 3, 2019].

Santos, Paula M. 2016. Crossed gazes over an old city: photography and the 'Experientiation' of a heritage place. International Journal of Heritage Studies 22 (2): 131-144.

Scarles, Caroline 2009. Becoming tourist: Renegotiating the visual in the tourist experience. Environment and Planning D: Society and Space 27(3): 465-488. 
Schroeder, Jonathan 2002. Visual consumption. London: Routledge.

Scruton, Roger 1979. The aesthetics of architecture. London: Methuen \& Co. Ltd.

Sekula, Allan 1981. The traffic in photographs. Art Journal 41 (1): 15-25.

Shanks, Michael 1997. Photography and archaeology. In: Brian Leigh Molyneaux (ed.) The cultural life of images: visual representation in archaeology. London: Routledge

Shanks, Michael and Connie Svabo 2013. Archaeology and photography: a pragmatology. In: Alfredo Gonzalez-Ruibal (ed) Reclaiming archaeology: Beyond the tropes of modernity. London: Routledge.

Shields, Rob 1991. Places on the margin: Alternative geographies of modernity. London: Routledge.

Shore, Stephen 2008. Photography and architecture. In: Christy Lange and Michael Fried Stephen Shore. London: Phaidon Press, 3-107.

Smiles, Sam and Stephanie Moser (eds) 2005. Envisioning the past: archaeology and the image. Oxford: Blackwell, 180-191.

Smith, Laurajane 2006. The uses of heritage. London: Routledge.

Sontag, Susan 1979. On photography. London: Penguin Books Ltd.

Sterckx, Marjan and Leen Engelen, Leen 2013. Between studio and snapshot: Belle époque picture postcards of urban statues, History of Photography 37 (4): 445-458.

Stylianou-Lambert, Theopisti 2012. Tourists with cameras: Reptoducing or producing? Annals of Tourism Research 39 (4): 1817-1838.

Sun, Minghui, Chris Ryan and Steve Pan 2014. Assessing tourists' perceptions and behavior through photographic and blog analysis: The case of Chinese bloggers and New Zealand holidays. Tourism Management Perspectives 12:125-133.

Tagg, John 1993. Burden of representation: Essays on photographies and histories. Minneapolis: University of Minnesota Press.

Terdiman, Richard 1993. Present past: Modernity and the memory crisis. Ithaca, NY: Cornell University Press.

Tomlinson, John 2007. The culture of speed: The coming of immediacy. London: Sage.

Urry, John 1990. The tourist gaze: Leisure and Travel in Contemporary Societies. London: Sage. Urry, John 1990. The Tourist Gaze: Leisure and travel in contemporary societies. London: Sage. Urry, John and Larsen, Jonas 2011. The tourist gaze 3.0. London: Sage.

Young, James E. 1990. The counter-monument: Memory against itself in Germany today. In: Mitchell William John Thomas (ed) Art and the public sphere. Chicago \& London: The University of Chicago Press, 49-78.

Young, James E. 1999. Memory and counter-memory. The end of the monument in Germany. Harvard Design Magazine 9: 1-10.

Wajcman, Gerald 2010. Un monumento invisibile. In: Cristina Baldacci and Clarissa Ricci (eds) Quando è scultura. Milan: Edizioni, 44-56. 
154 Mediating mediations of the past

Waner, Marina 2000 [1985]. Monuments and maidens, the allegory of the female form. London:

Picador.

Eirini Papdaki is Professor of Media and Visual Culture at the University of Ioaninna, Greece.

Email: E.papadaki@teiep.gr 